\title{
The Effect of Dosage, Number of Pesticides, Personal Protective Equipment Usage, Direction, Time, Duration and Spraying Frequency of Kolinesterase Content on Farmers in Gawu-Gawu Bouso Village North Gunungsitoli Sub-District, Gunungsitoli City
}

\author{
Eva Valentine Br. Hotang ${ }^{1}$, Taufik Ashar ${ }^{2}$, Wirsal Hasan ${ }^{3}$ \\ Department of Environmental Health, Faculty of Public Health, Universitas Sumatera Utara, Indonesia \\ evavalentine84@gmail.com
}

\begin{abstract}
Pesticide poisoning occurs when there is a certain amount of pesticide material that reaches and / or enters the body. Pesticide poisoning is influenced by many factors including dose, amount, time, length, direction and frequency of spray. This study was an observational study using a cross sectional design that aims to determine the effect of dosage, amount of pesticides, PPE usage, direction, time, duration and frequency of spraying on the level of cholesteresterase farmers in Gawu-Gawu Bouso Village, Gunungsitoli Utara District, Gunungsitoli City. The population includes farmers and farm laborers who spray pesticides in Gawu-Gawu Bouso Village, Gunungsitoli Utara District with 44 research samples. Data analysis uses univariate, bivariate (chi-square test) and multivariate analysis with logistic regression. The results of the bivariate analysis showed that there were 6 independent variables that had a significant relationship with cholinestrase namely dose, amount, direction of spray, time, duration and frequency of spray. This is indicated by the significance value of the 6 independent variables is $<0.05$. Multivariate test results showed that there were 4 of the 7 independent variables that had a significant effect on cholinesterase ie dose, amount, time, and frequency of spray) ( $p<0.05)$ while the other 3 variables namely personal protective equipment, spray direction and duration had no significant effect. The most influential variable on colliniestarase is dose.
\end{abstract}

Keywords: dosage; amount, direction; personal protective equipment; spray time; spray duration; spray frequency; cholinesterase

\section{Introduction}

The use of chemicals for insect pest control has been started for a long time by using inorganic chemicals such as sulfur and asphalt in the centuries $\mathrm{BC}$ and then the nature of arsenic poison was discovered in the first century BC.

Insecticide poisoning causes headaches, nausea, tremors, and damage to important organs such as the liver and kidneys. Accumulation of insecticides little by little in a long time can cause delayed effects which are more dangerous than diseases caused by receiving insecticides once in rather high levels. Delayed effects occur in the form of skin cancer, lung cancer and liver cancer (Wardhana, 2004).

The World Health Organization (WHO) estimates that 1 - 5 million cases of pesticide poisoning occur in farmers with a death rate reaching 220,000 people each year. Direct (acute) poisoning can reduce cholinesterase activity. Cholinesterase is an enzyme (a form of biological catalyst) in body tissues that acts to keep muscles, glands and nerve cells working in an organized and harmonious manner. Decreased cholinesterase activity will affect the muscle fibers consciously with smooth and rough movements as a result farmers experience eye irritation and weak muscle movements (Gallo, 1991).

Factors that influence the occurrence of pesticide poisoning are the characteristics of farmers, namely age, sex, nutritional status, level of education, length of work, behavior of farmers in using pesticides, among others, the many types of pesticides used, mixing the dose 
of pesticides, frequency of spraying, duration of spraying, usage personal protective equipment. (Djojosumarto, 2008).

The use of Personal Protective Equipment (PPE) is a risk factor that has the highest risk compared to other risk factors. The use of PPE includes wearing long-sleeved pants and clothes, gloves, masks or nose cover, boots / boots, hats and glasses (Asror et al, 2007).

Workers who manage pesticides must not experience exposure more than 5 hours a day and 30 hours a week.

A person who works in an environment containing pesticides is more likely to be exposed to pesticides, so the greater the possibility of poisoning, due to many contacts and inhaling (Sartono, 2002).

Based on a preliminary survey conducted on January 5, 2018, the use of pesticides in Gunungsitoli City is high. Farmers use 3-5 active substances of the organosphosphate group. The types of pesticides that are often used are dimehipo, sipermetrin, BPMC, Abamestin, mankozeb, carbofuran, diphenoconazole, methyl thiophyanate, carbandazim, isopropliamina glycophate, propineb, acetate, alpha cipmetrin.

The results of interviews of 15 respondents, after spraying farmers experienced health problems such as 9 people $(60 \%)$ farmers experienced watery eyes, 6 people (40\%) farmers experienced skin irritation, 8 people $(53.3 \%)$ farmers experienced dizziness and pain to 3 people (20\%) farmers had diarrhea. Rice farmers who do not use personal protective equipment such as hats, masks, gloves, work clothes when spraying (86.6\%) After spraying pesticides, farmers do not wash their hands thoroughly, do not change clothes, smoke immediately.

Based on data from the UPTD Puskesmas Gunungsitoli Utara District, showed that skin diseases, diseases of the muscular system and connective tissue, anemia occupy the 10 most diseases in this region.

Rice farmers in Gawu-Gawu Bouso Village also experienced health problems after spraying watery eyes $(60 \%)$, skin irritation $(40 \%)$, diarrhea $(20 \%)$, nausea and headaches (53.3\%). In addition, farmers use a mixture of 3-5 types of pesticides at once, with a frequency of spraying $1 \mathrm{x}$ a week. Farmers also do not use personal protective equipment when spraying.

To analyze the relationship between dosage, amount of pesticides, use of PPE, direction of spray against the wind, time of spraying, duration of spraying, frequency of spraying with the level of colinesterase farmers in Gawu-Gawu Bouso Village, Gunungsitoli Utara District, Gunungsitoli City.

\section{Research Methods}

This study was an observational study using a cross sectional design. The population in this study were farmers and farm workers who sprayed pesticides in Gawu-Gawu Bouso Village, North Gunungsitoli District.

Sample size is part of the number and characteristics possessed by the population. Research with cross sectional design, calculation of minimum sample size that must be taken for hypothesis testing using the following formula:

Inclusion criteria:

a. Paddy farmers who grow rice

b. Farmers who spray with $<2$ weeks spraying frequency

Exclusion Criteria:

a. Rice farmers who don't spray pesticides

b. Farmers who spray but not continuously 
The data in this study are primary data obtained by examining farmers' blood cholinesterase and interviews with questionnaires.

Secondary data were obtained from the Health Office of Gunungsitoli City, North Gunungsitoli Health Center, and Gunungsitoli City Agriculture Office.

Operational definition

a. Cholinesterase level is the amount of the level of cholinesterase activity in the blood expressed in percentage (\%) of the sampling method by examining blood preparations using the Tinto Meter Kit.

b. Pesticide dose is the amount of pesticide used in grams / cc units mixed with water solvent each time it is used.

c. Type of pesticide is the amount of type of pesticide used by farmers for once spraying plants.

d. Use of Personal Protective Equipment is the habit of respondents to use tools to protect themselves from the influence of pesticides when spraying.

e. Direction of spray against the wind is a directional or opposite spraying technique.

f.Spraying time is the time when the farmer does the spraying.

g. Duration of spraying is the time required to spray pesticides each time spraying

h. Frequency of spraying is the number of respondents spraying every week.

Dependent Variable

a. Pesticide poisoning

Measuring instrument: Questionnaire

How to measure: Tintometer kit

Measuring results:

- Normal (75 - 100\%)

- Mild poisoning (50 - 75\%)

- Moderate poisoning (25-50\%)

- Severe poisoning (0-25\%)

Then categorized into:

a. Normal (75 - 100\%)

b. Not normal $(<75 \%)$

Independent Variable

a. Dose of pesticides

- In accordance with the rules on the packaging label

- Not according to rules

b. The amount of pesticides used

- Single

- Mixed

c. Use of PPE

- Complete (using hats, masks, gloves, work clothes)

- Incomplete (do not use one of the hats, masks, gloves, work clothes).

d. Direction of spray against the wind

Measurement Results:

- In the direction of the wind

- Opposite direction with angina direction

e. Spraying time

- As recommended (if spraying time is at $08.00-11.00$ or at $15.00-18.00$ ) 
- Not as recommended (if spraying time is free)

f. Long time spraying

- As recommended (Spray duration $<4$ hours)

- Not suitable (Spray duration $\geq 4$ hours)

$\mathrm{g}$ Frequency of spraying pesticides

- As recommended (spray frequency $<2$ times per week).

- Not as recommended (if spray frequency $>2$ times per week)

Data analysis method

Univariate Analysis

All research variables are in the form of answers from respondents and the results of laboratory analysis are then presented in tabular form.

Bivariate Analysis

Bivariate analysis is useful to see the relationship between the independent variable (pesticide dose, amount of pesticide, PPE usage, direction of spray against wind, time of spraying, duration of spraying, frequency of spraying) with the dependent variable (cholinesterase activity). The type of data is categorical, so the analysis technique used is chi square. If the value of $\mathrm{p}<0.05$ means there is a significant relationship between the two variables.

\section{Multivariate Analysis}

Multivariate analysis is useful to see the effect of each variable together, namely the dose of pesticides, the amount of pesticides, the use of PPE, the direction of spray on wind, spraying time, duration of spraying, frequency of spraying on cholinesterase activity using multiple logistic regression statistical tests.

\section{Result}

\subsection{Univariate Analysis Results}

Pesticide Dose Frequency Distribution, Amount of Pesticide, PPE Usage, Direction of Spray, Time of Spray, Time of Spray, Frequency of Spray, Nutrition Status with Blood Cholinesterase Level in Gawu-Gawu Bouso Village in 2018.

\begin{tabular}{lcc}
\hline Variable & $\mathrm{N}=44$ & Percentage(\%) \\
\hline Number of Pesticides & & \\
Not according to rules & 20 & 45.5 \\
According to rules & 24 & 54.5 \\
Total Pesticide Mixture & & \\
Mix & 18 & 40.9 \\
Single & 26 & 59.1 \\
Use of Personal Protective Equipment & & \\
Do not use complete & 19 & 43.2 \\
Use complete & 25 & 56.8 \\
Spraying direction on Wind Direction & & \\
Opposite to the wind direction & 18 & 40.9 \\
As wind direction & 26 & 59.1 \\
Spraying Time & & \\
It is not in accordance with (08.00-11.00 or 15.00- & 13 & 29.5 \\
18.00) & & 70.5 \\
It is not in accordance with & 31 &
\end{tabular}




\begin{tabular}{lcc}
\hline Spraying Duration & & \\
$\geq 4$ hours per day & 11 & 25.0 \\
$<4$ hours per day & 33 & 75.0 \\
Spraying Frequency & & \\
$>2$ times a week & 18 & 40.9 \\
$\leq 2$ times a week & 26 & 59.1 \\
Nutritional status & & \\
Malnutrition & 2 & 4,5 \\
Normal & 42 & 95,5 \\
Blood Cholinesterase Levels & & \\
Abnormal & 15 & 34.1 \\
Normal & 29 & 65.9 \\
\hline
\end{tabular}

The majority of farmers use the appropriate pesticide dosage as many as 24 people (54.5\%). The majority of farmers use a single amount of pesticides as many as 26 people (59.1\%). Farmers who use Personal Protective Equipment are 25 people (56.8\%). 26 farmers $(59.1 \%)$ sprayed in the direction of the wind direction. Farmers who spray according to the recommendations as many as 31 people $(70.5 \%)$. The majority of farmers carried out long spray $<4$ hours ie as many as 33 people $(75.0 \%)$. The majority of farmers sprayed with spray frequency $\leq 2$ times a week, as many as 26 people $(59.1 \%)$. Cholinesterase in this study was categorized into 2 namely normal and abnormal, the majority of samples were with normal cholinesterase in 29 people $(65.9 \%)$.

\section{Bivariate Analysis Results}

Dosage, Number of Pesticides, Personal Protective Equipment Usage, Direction, Time, Duration and Spraying Frequencywith Blood Cholesterase Level.

\begin{tabular}{|c|c|c|c|c|c|c|c|c|}
\hline \multirow{3}{*}{ Variable } & \multicolumn{6}{|c|}{ Cholinesterase Levels } & \multirow{3}{*}{$\begin{array}{l}\mathrm{p} . \\
\text { value }\end{array}$} & \multirow{3}{*}{$\begin{array}{c}\mathrm{RP} \\
(95 \% \mathrm{CI})\end{array}$} \\
\hline & \multicolumn{2}{|c|}{ Abnormal } & \multicolumn{2}{|c|}{ Normal } & \multicolumn{2}{|c|}{ Total } & & \\
\hline & $\mathrm{n}$ & $\%$ & $\mathrm{n}$ & $\%$ & $\mathrm{n}$ & $\%$ & & \\
\hline \multicolumn{9}{|l|}{ Number of Pesticides } \\
\hline Not according to rules & 11 & 55,0 & 9 & 45,0 & 20 & 100 & \multirow{2}{*}{0,008} & 3,300 \\
\hline According to rules & 4 & 16,7 & 20 & 83,3 & 24 & 100 & & $(1,240-8,779)$ \\
\hline \multicolumn{9}{|l|}{ Total Pesticide Mixture } \\
\hline Mix & 10 & 55,6 & 8 & 44,4 & 18 & 100 & \multirow{2}{*}{0,012} & 2,889 \\
\hline Single & 5 & 19,2 & 21 & 80,8 & 26 & 100 & & $(1,187-7,032)$ \\
\hline \multicolumn{9}{|l|}{ Use of Personal } \\
\hline \multicolumn{9}{|l|}{ Protective Equipment } \\
\hline Do not use complete & 9 & 47,4 & 10 & 52,6 & 19 & 100 & \multirow{2}{*}{0.105} & 1,974 \\
\hline Use complete & 6 & 24,0 & 19 & 76,0 & 25 & 100 & & $(0,849-4,587)$ \\
\hline \multicolumn{9}{|l|}{$\begin{array}{l}\text { Spraying direction on } \\
\text { Wind Direction }\end{array}$} \\
\hline $\begin{array}{l}\text { Opposite to the wind } \\
\text { direction }\end{array}$ & 10 & 55,6 & 8 & 44,4 & 18 & 100 & \multirow[t]{3}{*}{0,012} & \multirow[t]{3}{*}{$\begin{array}{c}2,889 \\
(1,187-7,032)\end{array}$} \\
\hline As wind direction & 5 & 19,2 & 21 & 80,8 & 26 & 100 & & \\
\hline \multicolumn{7}{|l|}{ Spraying Time } & & \\
\hline It is not in accordance & 9 & 65,2 & 4 & 30,8 & 13 & 100 & \multirow[b]{2}{*}{0,001} & \multirow{3}{*}{$\begin{array}{c}3,577 \\
(1,600-7,999)\end{array}$} \\
\hline $15.00-18.00)$ & 6 & 104 & 25 & 806 & 31 & 100 & & \\
\hline It is not in accordance & & 19,4 & & & & 100 & & \\
\hline
\end{tabular}

with

Spraying Duration 


\begin{tabular}{lcccccccc}
$\geq 4$ hours per day & 9 & 65,2 & 4 & 30,8 & 13 & 100 & 0,001 & 3,577 \\
$\begin{array}{l}<4 \text { hours per day } \\
\text { Spraying Frequency }\end{array}$ & 6 & 19,4 & 25 & 80,6 & 31 & 100 & & $(1,600-7,999)$ \\
$\begin{array}{l}>2 \text { times a week } \\
\leq 2 \text { times a week }\end{array}$ & 10 & 55,6 & 8 & 44,4 & 18 & 100 & & \\
Nutritional status & 5 & 19,2 & 21 & 80,8 & 26 & 100 & 0,012 & $(1,187-7,032)$ \\
$\begin{array}{l}\text { Malnutrition } \\
\text { Normal }\end{array}$ & 1 & 50,0 & 1 & 50,0 & 2 & 100 & 1,000 & 2,000 \\
\hline
\end{tabular}

Multivariate Analysis Results

\begin{tabular}{|c|c|c|c|c|}
\hline Stage & Variable & Exp.B & Coefficient (B) & $\mathrm{p}$ \\
\hline \multirow[t]{7}{*}{1} & Constant & & $-6,458$ & \\
\hline & Dosage of Pesticides & 75,521 & 4,324 & 0,022 \\
\hline & Number of Pesticides & 39,527 & 3,677 & 0,044 \\
\hline & $\begin{array}{l}\text { Personal Protective } \\
\text { Equipment }\end{array}$ & 0,034 & $-3,376$ & 0,134 \\
\hline & Spraying Direction & 0,989 & $-0,011$ & 0,994 \\
\hline & Spraying Time & 72,060 & 4,277 & 0,019 \\
\hline & Spraying Frequency & 87,875 & 4,476 & 0,005 \\
\hline \multirow[t]{6}{*}{2} & Constant & & $-6,458$ & \\
\hline & Dosage of Pesticides & 75,500 & 4,324 & 0,021 \\
\hline & Number of Pesticides & 39,348 & 3,672 & 0,034 \\
\hline & $\begin{array}{l}\text { Personal Protective } \\
\text { Equipment }\end{array}$ & 0,034 & $-3,375$ & 0,133 \\
\hline & Spraying Time & 71,682 & 4,272 & 0,12 \\
\hline & Spraying Frequency & 87,624 & 4,473 & 0,004 \\
\hline \multirow[t]{5}{*}{3} & Konstanta & & $-5,931$ & \\
\hline & Dosage of Pesticides & 13,757 & 2,622 & 0,058 \\
\hline & Number of Pesticides & 14,476 & 2,672 & 0,054 \\
\hline & Spraying Time & 36,820 & 3,606 & 0,022 \\
\hline & Spraying Frequency & 51,538 & 3,942 & 0,008 \\
\hline \multirow[t]{4}{*}{4} & Konstanta & & $-5,273$ & \\
\hline & Number of Pesticides & 42,783 & 3,756 & 0,008 \\
\hline & Spraying Time & 37,964 & 3,637 & 0,006 \\
\hline & Spraying Frequency & 42,783 & 3,756 & 0,008 \\
\hline
\end{tabular}

The results of multiple logistic regression tests showed that of the 7 independent variables, there were 4 (four) variables that had a significant effect on cholinesterase, namely the dose of pesticides, the amount of pesticides, the time and frequency of the spray. This is indicated by the 4 sig-p values of these variables are $0.037,0.043,0.032$ and 0.020 all four are smaller than 0.05 .

\section{The Most Dominant Variable Influential}

Based on the value of $\operatorname{Exp}(B)$, it can be seen that the most influential variable on cholinesterase is as follows:

The Most Dominant Variables Effects on Cholinesterase 
emails: birex.journal@gmail.com

\begin{tabular}{clc}
\hline No & \multicolumn{1}{c}{ Variable } & $\operatorname{Exp}(\mathbf{B})$ \\
\hline 1 & Dosage of Pesticides & 60.807 \\
2 & Number of Pesticides & 47.737 \\
3 & Spraying Time & 55.033 \\
4 & Spraying Frequency & 49.898 \\
\hline
\end{tabular}

Based on the Ex $(\bar{B})$ value, it is known that the most dominant variable influencing cholinesterase is the pesticide dose variable with the value of $\operatorname{Exp}(B)=60,807$ followed by the spray time variable with the value $(\operatorname{Exp}(B)=55,033$

\section{Discussion}

\subsection{Effects of Pesticide Doses on Cholinesterase}

Descriptive analysis results prove that the majority of samples have an appropriate dose of pesticides as many as 24 people $(54.5 \%)$ and the majority of samples are with normal cholinesterase which is as many as 29 people $(65.9 \%)$. This shows that there is a linear relationship between the dose of pesticides with cholinesterase, where the more appropriate the pesticide dose the more normal is cholinesterase. The results of the chi-square test show that the t-value $=5,530$ and $\mathrm{p}$-value $=0.019$, smaller than 0.05 , p this means that the dose of pesticide has a significant relationship with cholinesterase. Odd ratio value is 6.11 which is between 1.52 and 24.5 which means that if the pesticide dose is suitable, the possibility of experiencing normal cholinesterase is 6.11 times.

The results of this study are in line with the research of Mirzadevi (2007) factors related to pesticide poisoning in pest sprayers in Pedeslohor Village, Adiwerna Subdistrict, Tegal Regency, where the results of the study prove that the dose and amount of pesticides, PPE usage, how to spray, spraying time and duration have a relationship significant with the incidence of pesticide poisoning.

The importance of dose measurement is that the way to determine the level of pesticide poisoning is by measuring the level of cholinesterase in the blood. Someone who experiences complaints due to pesticide poisoning generally has low levels of cholinesterase. Some pesticides are anti-cholinesterase which can reduce the work activity of cholinesterase enzymes in the body. Examples of pesticides that inhibit cholinesterase activity are the organophosphate group and the carbamate group (Budiawan, 2013).

\subsection{Effects of the Amount of Pesticides on Cholinesterase}

Descriptive analysis results prove that the majority of the sample has a single amount of pesticides as many as 26 people $(59.1 \%)$ and the majority of samples are with normal cholinesterase which is as many as 29 people $(65.9 \%)$. This shows that there is a linear relationship between the amount of pesticides with cholinesterase, where the more single the amount of pesticides the more normal the cholinesterase. Chi-square test results showed that the value of $\mathrm{t}$-count $=4730$ and $\mathrm{p}$-value $=0.030$, smaller than 0.05 , this means that the amount of pesticides has a significant relationship with cholinesterase. Odd ratio value is 5.24 which is between 1.36 and 20.19 which means that if the number of pesticides is single, the chance of experiencing normal cholinesterase is 5.24 times.

The results of this study are in line with Rihardi's research, 2016, The Relationship Between Pesticide Poisoning and Anemia in Potato Farmers in the Al-Farruq Farmers Group in Patak Banteng Village, Kejajar Subdistrict, Wonosobo District in 2016 where the results showed that there was a relationship between the number of pesticides $(p=0.001)$ and the use of PPE ( $p=0.049)$ with the occurrence of cholinesterase. 
Cholinesterase is an enzyme that is in the body's tissues which has a role to keep nerve cells, muscles and glands working properly. When cholinesterase activity reaches a low level of about $20 \%$ of normal conditions, symptoms of poisoning will be seen, such as the pupils or iris slits narrowed so that vision blurred. tears out due to weakened muscle movements, excessive salivation, nausea, dizziness, convulsions, vomiting, rapid heartbeat, shortness of breath, muscles can not be moved so that fainting and respiratory muscles begin to paralyze can cause death (Wudianto, 2002).

According to other studies the factors associated with the incidence of pesticide poisoning on shallot farmers are the amount of pesticides used in agricultural activities and how to spray (Isnawan, 2013).

Farmers' habits in using pesticides sometimes violate the rules. Farmers who spray using more than 1 type of pesticide are 4.68 times more likely to have abnormal levels of cholinesterase in the blood than farmers who spray using 1 type of pesticide. There are $91.3 \%$ of farmers who use 1 type of pesticide have normal cholinesterase levels (Afriyanto, 2008).

\subsection{The Effect of Use of Personal Protective Equipment on Cholinesterase}

Descriptive analysis results prove that the majority of samples using Personal Protective Equipment (PPE) as many as 25 people (56.8\%) and the majority of samples are with normal cholinesterase that is as many as 29 people $(65.9 \%)$. This shows that there is a linear relationship between Personal Protective Equipment and Cholinesterase, where the more Personal Protective Equipment is used, the more normal is Cholinesterase. Chi-square test results showed that the value of $\mathrm{t}$-count $=1.687$ and $\mathrm{p}$-value $=0.194$, greater than 0.05 , this means that the use of Personal Protective Equipment has no significant relationship with cholinesterase. Odd ratio value is 2.85 which is between $0.78-10.31$ which means that if you wear Personal Protective Equipment, the chance of experiencing normal cholinesterase is 2.85 times.

The results of this study are in line with the study of Zuraida (2012) Factors related to pesticide poisoning in farmers in Srimahi Desa Tambun Utara Bekasi 2011 where the results of the study prove that the use of Personal Protective Equipment and pesticide use procedures do not have a significant relationship with pesticide poisoning. .

Risk factors for pesticide poisoning include, age, sex, knowledge, experience, skills, education, use of personal protective equipment, nutritional status, pesticide management practices (Mufidah, Wahyuni, \& Pranowowati, 2016).

\subsection{Effect of Spray Direction on Cholinesterase}

Descriptive analysis results prove that the majority of samples with unidirectional spray of 26 people $(59.1 \%)$ and the majority of samples are with normal cholinesterase of 29 people $(65.9 \%)$. This shows that there is a linear relationship between the direction of the spray with cholinesterase, where the more direct the spray the more normal the cholinesterase. Chisquare test results showed that the value of $\mathrm{t}$-count $=4734$ and $\mathrm{p}$-value $=0.030$, smaller than 0.05 , this means that the direction of spray has a significant relationship with cholinesterase. Odd ratio value is 5.25 which is between 1.36-20.19 which means that if the spray is unidirectional, the possibility of experiencing normal cholinesterase is 5.25 times.

The results of this study are in line with Apriyanto's research (2008), Study of Pesticide Poisoning in Chili Spraying Farmers in Candi Village, Bandungan Subdistrict, Semarang Regency where the results showed that the risk factors affecting pesticide poisoning were dose, duration of spraying, direction of spray against wind direction, knowledge , attitude, cleanliness of the body and the use of PPE.

Pesticides have several negative effects on their users. This is related to their activities in agriculture, such as spraying, preparing equipment for spraying, including mixing 
pesticides, washing equipment or clothes used for spraying, removing grass from plants, looking for pests, and harvesting (Kurniasih, Setiani, \& Nugraheni, 2013 ).

Spraying techniques that sometimes go downwind, cause farmers to inhale pesticides without realizing it. Behavior of excessive use of pesticides like that would cause a new problem that is the presence of pesticide residues on agricultural products and ultimately endanger farmers and the wider community both for safety and health at work (MOH, 2006).

Impact on health can occur through the skin, breathing and digestion in the form of acute and chronic poisoning. Symptoms of acute pesticide poisoning such as headaches, nausea, vomiting, and even some pesticides can cause skin irritation and blindness. In chronic poisoning it is not easily detected because its effects are not immediately felt (Marsaulina \& Wahyuni, 2007).

\subsection{Effect of Spray Time on Cholinesterase}

Descriptive analysis results prove that the majority of samples are with the recommended spray time of 31 people $(70.5 \%)$ and the majority of samples are with normal cholinesterase of 29 people $(65.9 \%)$. This shows that there is a linear relationship between spray time and cholinesterase, where the more appropriate the recommended spray time the more normal the cholinesterase. The results of the chi-square test showed that the Fisher's ttest value $=9,953$ and $p$-value $=0.002$, smaller than 0.05 , this meant that the spray time had a significant relationship with cholinesterase. Odd ratio value is 9.37 which is between 2.1441.05 which means that if you spray while, the chance of experiencing normal cholinesterase is 9.37 times.

\subsection{Effect of Spray Duration on Cholinesterase}

Descriptive analysis results prove that the majority of samples are $<4$ hours long with spray of 33 people $(75.0 \%)$ and the majority of samples are with normal cholinesterase of 29 people $(65.9 \%)$. This shows that there is a linear relationship between the length of the spray and cholinesterase, where the shorter the spray time the more normal the cholinesterase.

The results of the chi-square test showed that the Fisher's t-test value $=9,953$ and $p$-value $=$ 0.002 , smaller than 0.05 , this meant that the spray time had a significant relationship with cholinesterase. Odd ratio value is 9.37 which is between 2.14-41.05 which means that if you spray while, the chance of experiencing normal cholinesterase is 9.37 times.

The results of this study are in line with Suparti (2016) Some Risk Factors Affecting Pesticide Poisoning in Farmers where the results of the study prove that the factors proven to be risk factors for organophosphate poisoning are pesticide doses $(\mathrm{p}=0.002$; OR adjusted 8.36; $95 \%$ CI 2.23-31-33), duration of spraying ( $\mathrm{p}=0.002$; OR adjusted 5.60; 95\% CI 1.8716.77),

\subsection{Effect of Spray Frequency on Cholinesterase}

Descriptive analysis results prove that the majority of samples are with spray frequency $\leq 2$ times a week, as many as 26 people $(59.1 \%)$ and the majority of samples are with normal cholinesterase, which is 29 people $(65.9 \%)$. This shows that there is a linear relationship between the frequency of the spray and cholinesterase, where the less frequent the spray frequency is, the normal is also cholinesterase. Chi-square test results showed that the value of t Continuity correction $=4.734$ and $p$-value $=0.030$, smaller than 0.05 , this means that the frequency of spray has a significant relationship with cholinesterase. Odd ratio value is 5.25 which is between 1.36-20.19 which means that if the spray frequency is $\leq 2$ times a week, the chance of experiencing normal cholinesterase is 5 times.

The results of this study are not in line with the 2015 Eka Lestari study, Risk Factors in the Use of Pesticides on Health Complaints in Farmers in Berastagi District in Karo District 
in 2014 where the results of the study proved that the frequency of spraying had no relationship with health complaints.

Pesticides are poisons that are very dangerous to humans, so safety factors in using pesticides need to be given priority. Ideally, pesticides can kill disease-carrying insects and pests on plants, but they are not poisonous to humans and other living things, which are not targets. Pesticides are poisonous materials, so they are very dangerous if not managed properly and correctly, especially farmers whose activities are directly related to pesticides (Kariani.N, 2008).

Spraying pesticides that do not meet the rules, including the frequency of spraying, will have many impacts, including human health impacts, that is poisoning to farmers which can be done by checking blood cholinesterase activity. Factors that influence the occurrence of pesticide poisoning are factors from the body (internal) and from outside the body (external). Factors from the body include age, sex, genetics, nutritional status, hemoglobin levels, level of knowledge and health status. While factors outside the body have a large role such as the amount of pesticides used, types of pesticides, pesticide doses, frequency of spraying, working period of being sprayers, duration of spraying, use of personal protective equipment, how to handle pesticides, last contact with pesticides, plant height, temperature environment, spraying time and actions towards angina (WHO, 2011).

\section{Conclusion}

Doses of pesticides have a significant relationship and influence on cholinesterase. This is indicated by the value of sig-p (pesticide dose) $=0.037<0.05$

a. The amount of pesticides has a significant relationship and influence on cholinesterase. This is indicated by the value of sig-p (number of pesticides) $=0.043$ $<0.05$

b. The use of PPE has no significant relationship and influence on cholinesterase. This is indicated by the value of sig-p (PPE usage) $=0.194<0.05$

c. Direction has a significant relationship with cholinesterase but does not have a significant effect on cholinesterase. This is indicated by the value of sig-p (time) $=$ $0.614>0.05$

d. Time has a significant relationship and influence on cholinesterase. This is indicated by the value of sig-p (time) $=0.032<0.05$

e. Lama has a significant relationship with cholinesterase but has no significant effect. This is indicated by the value of sig-p (time) $=0.382<0.05$

f. Spray frequency has a significant relationship and influence on cholinesterase. This is indicated by the value of sig-p (frequency) $=0.020<0.05$

g. The most dominant variable influences on cholinesterase is pesticide dose variable with Exp value $(B)=60,807$ followed by spray time variable with value $(\operatorname{Exp}(B)=$ 55,033 .

\section{References}

Achmadi, U.F., 2005. Dasar-dasar Penyakit Berbasis Wilayah.Jakarta :PT. Kompas Media Nuswantoro.

Afriyanto., 2008. Kajian Keracunan Pestisida Pada Petani Penyemprot Cabe Di Desa Candi Kecamatan Bandungan Kabupaten Semarang (Tesis), Semarang: FKM UNDIP Press.

Asror, F., Sulistiyani., Hanani. Yusniar., 2007, Faktor Risiko Kejadian Keracunan Pestisida Organosfosfat pada Petani Hortikultura di Kecamatan Ngablak Kabupaten Magelang: Jurnal kesehatan Lingkungan Indonesia, volume 6, No.2 Oktober 2007 
Departemen Tenaga Kerja. Permenaker No.Per-03/Men/1986 tentang Keselamatan dan Kesehatan Kerja di Tempat Kerja yang Mengelola Pestisida.

Djojosumarto, P., 2008. Teknik Aplikasi Pestisida Pertanian, Yogjakarta: Kanisius.

2008. Pestisida dan Aplikasinya, Yogyakarta: Kanisius.

Departemen Kesehatan Republik Indonesia, 2006 Peraturan Perundang-Undangan yang Berkaitan dengan Pestisida, Direktorat Jenderal Pemberantasan Penyakit Menular dan Penyehatan Lingkungan Pemukiman, Jakarta,

Gallo, M., 1991.Organic Phosphorus Pesticides.Handbook of Pesticide Toxicology.

Gossel, T., 1990.Principle of Clinical Toxicology, New York: Raven Press.

Kariani.N. hubungan antara lama paparan pengetahuan dan perilaku dengan aktivitas cholinesterase darah petani. Airlangga university, 2008

Ketaren, V., 2013.Pengaruh Paparan Pestisida Terhadap Aktivitas Kholinestrase Darah Pada Petani Tomat di Kecamatan Teran Kabupaten Karo Tahun 2013.Medan :Tesis Universitas Sumatera Utara

Lemeshow, S., David, W., Janelle, K., and Stephen, K., 1997. Besar Sampel dalam Penelitian Kesehatan (Terjemahan Dibyo Pramono), Yogyakarta : Gadjah Mada University Press.

Ma'arif, M.I., Suhartono., Yunita, N..A., 2016.Studi Prevalensi Keracunan Pestisida Pada Petani Penyemprot Sayur di Desa Mendongan Kecamatan Sumowono Kabupaten Semarang, Jurnal Kesehatan Masyarakat, Volume 4 Nomor 5 Oktober 2016.

Mufidah, A.R., Wahyuni, S. \& Pranowowati, P. 2016. Hubungan antara Pemakaian APD (Alat Pelindung Diri) dengan Kadar Kolinesterase Darah pada Petani Holtikultura di Desa Bumen Kecamatan Sumowo Kabupaten Semarang. Ungaran: Sekolah Tinggi Ilmu Kesehatan Ngundi Waluyo.

Mualim K. Analisis Faktor Risiko yang Berpengaruh terhadap Kejadian Keracunan Pestisida Organofosfat pada Petani Penyemprot hama Tanaman di Temanggung. Universitas Diponegoro; 2002.

Notoatmodjo, S., 2010. Metodologi Penelitian Kesehatan, Edisi Revisi, Jakarta : Rineka Cipta

Novisan., 2002. Membuat dan Memanfaatkan Pestisida Ramah Lingkungan, Jakarta: Agro Media Pustaka.

Peduto, V., 1996.Carbamate and Organophosphate Poisoning, Minerva Anestestor.

Peraturan Menteri Pertanian Nomor : 07/PERMENTAN/SR.140/2/2007 tentang Syarat dan Tata Cara Pendaftaran Pestisida, Jakarta.

Peraturan Pemerintah Repbublik Indonesia No. 6 Tahun 1995 tentang Perlindungan Tanaman, Jakarta.

Prihadi.Faktor-faktor yang berhubungan dengan Efek Kronis Keracunan Pestisida Organofosfat Pada Petani Sayuran di Kecamatan Ngablak Kabupaten Magelang, PPsUNDIP, Semarang, 2008 dan Puskesmas Ngablak.

Prijanto, T. B., Nurjazuli., Sulistiyani., 2009. Analisis Faktor Risiko Keracunan Pestisida Organosfosfat Pada Keluarga Petani Hortikutura di Kecamatan Ngablak kabupaten Magelang : Jurnal Kesehatan Lingkungan Indonesia, Volume 8 no.2 Oktober 2009.

Rahayuningsih, E., 2009. Perilaku Pestisida di tanah, Yogyakarta : Gadjah Mada University Press.

Rustia, H., Wispriyono, B., Susanna, D., Luthfiah, F.N., 2010. Lama Pajanan Organofosfat Terhadap Penurunan Aktivitas Enzim Kolinesterase Dalam Darah Petani Sayuran, Depok: Makara, Kesehatan, Volume 14, no.2 Desember 2010.

Sartono.,2002. Racun dan Keracunan, Jakarta : Wydia Medika

Sastrawijaya, A.T., 2009. Pencemaran Lingkungan, Jakarta : Rineka Cipta

Sembel, D., 2015. Toksikologi Lingkungan, Yogyakarta: Andi Offset. 
Soemirat, J., 2015. Toksikologi Lingkungan, Yogyakarta: Gadjah Mada University Press.

Sudarmo, S., 1991. Pestisida, Yogyakarta : Kanisius

Sutikno, S., 2002. Dasar-dasar dan Dampak Penggunaan Pestisida, Jakarta: PT. Gramedia Pustaka Utama.

Suparti, Sri., Anies., Setiani, Onny., 2016. Beberapa Faktor Risiko Yang Berpengaruh Terhadap Kejadian Keracunan Pestisida Pada Petani, Semarang : Jurnal Pena Medika, volume 6 No. 2, Desember 2016.

US EPA., 2004. Environmental Health Criteria XXX: Principles for Modelling, DoseResponse for The Risk Assessment of Chemical, Geneva: IPCS and World Health Organization.

Wardhana, W.W., 2004. Dampak Pencemaran Lingkungan, Yogyakarta : Andi Offset

Wijana, N., 2014. Ilmu Lingkungan, Yogyakarta : Graha Ilmu.

World Health Organization. 2000. Bahaya Bahan Kimia pada Kesehatan Manusia dan Lingkungan (Terjemahan Palupi Widyastuti), Jakarta : EGC

WHO, IARC, 2011Occupational Expousures Insecticide Application And Some Pesticide

Wudianto, Rini. Petunjuk Penggunaan Pestisida. Jakarta : PT Penebar Swadaya, 2002.

Yuantari, M., 2009. Studi Ekonomi Lingkungan Penggunaan Pestisida dan Dampaknya pada Kesehatan Petani di Area Pertanian Hortikultura Desa Sumber Rejo Kecamatan Ngablak Kabupaten Magelang, Jawa Tengah : Tesis FKM UNDIP 